\title{
Bireylerin Risk Azaltma Stratejilerini Etkileyen Faktörler Üzerine Ampirik Bir Araștırma
}

\section{Sibel DINÇ AYDEMIR', Selim AREN²}

Makale Gönderim Tarihi: 29.05.2015

Makale Kabul Tarihi: 22.01.2016

\section{Öz}

Bireylerin artan kișisel sorumluluklarından ötürü, risk azaltma stratejilerini yönetmede bireysel sigorta tercihlerini etkileyen güdülerin tespiti öncekinden daha önemli hale gelmiștir. Araștırma tip A davranıșı, kontrol odağı, heyecan arama, kaygılı olma, finansal risk toleransının sigorta tercihlerindeki rolünü sorgulamayı amaçlamaktadır. 71 kișilik örneklem veri setine uygulanan analiz sonuçları kaygılı olma, kontrol odağının tip A davranıșı üzerinde, bu davranıșının ve heyecan aramanın finansal risk toleransı üzerinde, finansal risk toleransının sigorta sayısında etkili olduğunu göstermiștir.

Anahtar Kelimeler: Kontrol Odağı, Heyecan Arama, Tip A Kișiliği, Finansal Risk Toleransı, Sigorta Tercihleri.

\section{An Empirical Study on Psychological Motives for Individuals' Risk Mitigating Strategies}

\section{Abstract}

Due to their increasing responsibility in risk mitigating strategies, understanding motives for insurance preferences is more important than before. This study aims to explore anxiety,

Uzman, Gebze Teknik Üniversitesi, İșletme Fakültesi, saydemir@gtu.edu.tr.

2 Prof. Dr. Yıldız Teknik Üniversitesi, İ̈BF, saren@yildiz.edu.tr. 
locus of control (LoC), type A, sensation seeking and financial risk tolerance (FRT)'s role on insurance preferences. Results indicate that (a) anxiety and LoC as significant on type a personality, (b) type a and sensation seeking as notable on FRT and (c) FRT as important on insurance preferences.

Keywords: locus of control, sensation seeking, type a personality, financial risk tolerance, insurance preference.

\section{Gíriș}

Bireyler emeklilik planları ya da risk azaltma stratejilerini yönetmek noktasında öncekine nazaran daha aktif ve sorumlu olmaya bașlamıștır. Bu bakımdan, bireylerin risk azaltma tercihlerini etkileyen faktörleri belirleyebilmek giderek önem kazanmaktadır. Bireylerin riskleri algılayabilmeleri ve yönetebilmeleri noktasında, objektif risk ölçütlerinin yanı sıra, riske karșı olan tutumları, finansal risk almaya yönelik toleransları, kișilik faktörleri ve duygusal etmenler de ön plana çıkmaktadır. Çünkü finansal risk alma, yönetme ve riski transfer etme stratejilerinin finansal yüklenimleri kadar duygusal cepheleri de bulunmaktadır.

Anbar ve Eker (2009:s. 130) riski, "gelecekte beklenmeyen olayların ortaya çıkma olasılığı" olarak tanımlamaktadır. Nitekim klasik finans teorisinde, bir tercihin riskliliği onun varyansıyla denk tutulmaktadır. Sitkin ve Pablo (1992:s. 10) riski, kararların muhtemel önemli ve/veya ters sonuçlarına ilișkin belirsizliğin derecesi olarak tarif etmektedir. Kișilerin bu belirsizliğe katlanmak anlamında farklılık gösterdiği genel bir kabuldür.

Finansal risk toleransı bir kimsenin finansal bir karar verirken kabul edebileceği maksimum belirsizlik miktarı olarak tanımlanabilir (Grable, 2000:s.625). Bu kavram, finansal bir dizi riskli duruma yönelik kișinin risk alma tavrını ölçmektedir. Bu noktada, risk alma tutumunun finansal düzleme tașınmıș hali olduğu söylenebilir. Weber ve diğerleri (2002)'e göre bir kimsenin risk tutumu, o kimsenin bir dizi riskli seçim alternatiflerinden çıkan fayda fonksiyonunu tanımlamaktadır. Roszkowski ve diğerleri (2005), risk tutumunun bireyin ne kadar risk alabileceği, risk kapasitesinin bireyin ne kadar risk almaya gücünün yeteceği, risk toleransının ise risk 
tutumu ve risk kapasitesinin bir bileșimi olarak literatürde geçtiğini belirterek, kavramları birbirinden ayırmaktadır.

Yatırım bağlamında Sachse ve diğerleri (2012) literatürde kullanılan yaygın risk ölçütlerini bir bütün altında toplamakta ve bunlardan bir risk algısı ölçeği olușturmaktadır. Çalıșmanın hareket noktası, bir yatırımın riskinin yatıımcılar için farklı manalara gelebilmesidir. Bu kapsamda, bir yatırımın riski, o yatırıma ilișkin öngörülebilirlik, ilgilenme, endișe, kaybın olasılığı, kayıp miktarı, değișkenlik, likidite, yenilik, șeffaflık, yatırım yapma isteği ile birlikte değerlendirilebilir (McGregor, Slovic, Berry, \& Evensky, 1999; Koonce, McAnally, \& Mercer, 2005). Daha açık bir ifadeyle, örneğin bir yatırıma yönelik duyulan endișe ne kadar fazla, bir yatırımın getirisi ne kadar inișli-çıkıșlı, bir yatırımın kayıp olasılığı ya da kayıp miktarı ne kadar yüksek, bir yatıımın nakde çevrilebilme yeteneği ne kadar az ise o yatırım riskli algılanmaktadır.

Son olarak, klasik finans teorisinde objektif risk ölçütleri (örneğin, riske maruz değer, beklenenden sapma) çoğunlukla kullanılmakładır (örn., Siebenmorgen \& Weber, 1999). Diğer taraftan, davranıșsal finans bakış açısında, riskin subjektif doğasına vurgu yapılarak, riskten kaçınma tutumu bașta olmak üzere riskten kaçınmaya yol açabilecek belli bașlı bireysel farklılıklar, çeșitli duygusal ya da bilișsel yanlılıklar yatırıma ilișkin risk algısının değerlendirilmesinde önem arz etmektedir. Buradan hareketle, bu çalıșmanın kuramsal arka planında davranıșsal finans bakıș açısının yattığını dile getirmekte de fayda vardir.

Öte yandan, bireyler günlük hayatları içinde karșılașabilecekleri riskleri yönetebilmek ve kontrol edebilmek için, en önemlisi bu risklerin zararlı etkilerinden bertaraf olmada sigorta ürünlerini kullanmaktadır. Literatürde bir risk azaltma stratejisi olarak sigorta tedbirinden sıkça söz edilmektedir (Bakınız Botzen, Aerts, \& Van Den Bergh, 2009; Ozdemir \& Yilmaz, 2011). Buradan yola çıkarak, bu çalıșma risk azaltma stratejilerinin bir göstergesi olarak sigorta tercihleri ve sayısını etkileyen faktörleri sorgulamayı amaçlamaktadır. Bu çalıșmanın, sonuçları itibariyle, riski yönetebilme tercihlerini açıklamada kișilik faktörleri ve tutumsal güdülere ișaret etmesi suretiyle literatüre katkı yapması beklenmektedir. 
Makalenin diğer bölümlerinde, sırasıyla mevcut literatürü ortaya koymak ve araștırma hipotezlerine dayanak olușturmak üzere literatür taraması, araștırma metodolojisi, tartıșma ve sonuç bölümleri yer alacaktır.

\section{Literatür Taraması}

\subsection{Tip A Davranıșı, Kaygılı Olma, Kontrol Odağı, Heyecan Arama}

Konu finansal risk alma olduğunda, finansal etmenler kadar kișilik faktörleri de önemli olmaktadır (Carducci ve Wong, 1998). Buna göre, mevcut literatürde Tip A davranıș kalıbı ve heyecan arama finansal risk alma ile ilișkilendirilen kișisel etmenler olarak ortaya çıkmaktadır. Bond ve Feather (1988) ise bireylerin kendilerini yapılandırma ve amaca yönelik olmada zamanı kullanmaya yönelik algılarının anlamlı bir psikolojik değișken olacağını öngörmektedir. Tip A davranıș kalıbının zaman baskısı, rekabet güdüsü ve iș baskısı algısı cepheleri bulunmaktadır. Tip A davranıșını sergileyen bireylerin hırslı, agresif, rekabetçi ve sabırsız olmaya eğilimli oldukları varsayılmaktadır (Mudrack, 1999). Aynı zamanda hızlı konușmak, iși hızlı yapmak eğiliminde olup zaman baskısı yașadıkları da düșünülmektedir. Carducci ve Wong (1998), Tip A davranıș kalıbını sergileyen bireylerin Tip B davranıșını gösterenlere kıyasla daha fazla finansal risk aldıklarını ortaya koymaktadır. Buradan yola çıkarak, bu araștırmada Tip A kișiliğinin finansal risk toleransı ile bağlantısı kurulmaktadır. Price (1982) tarafından ortaya atılan bilișsel sosyal öğrenme modeline göre, bilme yetisi, kișisel inanç ve korkular doğrudan Tip A davranıș kalıbı üzerinde etkili olabilir, bu da sırasıyla çeșitli psikolojik, tutumsal ve davranısssal çıktıları etkileyebilir. Buna dayanarak bireylerin son zamanlarda ne kadar kaygllı hissettiklerinin Tip A davranıșı üzerinde etkisi olabileceği öngörülmektedir.

Aynı șekilde olayların çıkılarını dıșsal faktörlere ya da bireyin kendi eylemlerine ilișkilendirme derecesini temsil eden kontrol odağının da bu davranıș kalıbını etkilemesi muhtemel görünmektedir. Rotter (1966) davranıș ile pekiștirme arasındaki nedensel ilișkinin kișiler tarafından farklı algılanabileceğini öne sürmekte- 
dir. Buna göre, davranıșı takip eden pekiștireç ya da ödül, birey tarafından kendi eyleminin sonucuymuș gibi değil de, talih, șans, kader ya da onun gibi diğer güçlerin kontrolündeymiș gibi algılanabilir. Eğer bir olay, birey tarafından bu biçimde algılanırsa, - kișinin dıșsal kontrol odağına sahip olduğu ileri sürülmektedir. Eğer kiși, olayı kendi eylemine ya da kendine has, değișmez özelliklerine bağlarsa, bu kișinin içsel kontrol inancına sahip olduğu kabul edilmektedir.

İçsel ve dıșsal kontrol odağı bir kișilik değișkeni ölçümü olarak araștırmalarda kullanılmaktadır. İçsel kontrol odağı ile risk alma arasındaki olumlu ilișkiyi ortaya koyan çalıșmaların çok büyük çoğunluğu girișimcilik literatüründe yeralmaktadır (örn., Miller ve Friesen, 1982; Kroeck ve diğerleri, 2010; Niammuad ve diğerleri, 2014) İçsel ve bireysel bir faktör olarak kontrol odağının davranıș ile olan ilișkisi, konunun davranıșsal finans çerçevesinde de ele alınmasını mümkün kılmaktadır. Grable ve Joo (2000), diğer faktörler sabitken, içsel kontrol odağının, finansal bilgi ve cinsiyetin finansal risk toleransı tahmin edicilerinden olduğu sonucuna varmaktadır. Ayrıca, kontrol odağı değișkeninin finansal risk toleransını açıklamaya katkısı diğer iki değișkenden daha fazla olmaktadır. Buna ilaveten, Perry ve Morris (2005) kontrol odağının sorumlu finansal davranış göstermede hem doğrudan hem dolaylı etkisi olduğunu göstermektedir.

Bu bulguların ıșığında, kaygılı olma halinin ve kontrol odağının Tip A davranıș kalıbı ile olumlu biçimde ilișkide olacağı, Tip A davranıș kalıbının da finansal risk toleransını olumlu etkileyeceği düșünülmektedir.

Heyecan arama, bireylerin çeșitli, özgün ve karmașık heyecanlar duyma ihtiyacı ve bu türden deneyimler yașamak üzere fiziksel ve sosyal risk alma isteklilikleri olarak tanımlanmaktadır (Zuckerman, 1979:s. 10). Buradan hareketle, çeșitli risk ortamlarında heyecan aramanın etkileri ortaya konmaktadır (örn., Heine ve diğerleri, 1996; Horvath \& Zuckerman, 1993; Hoyle ve diğerleri, 2000). Buna açıklama olarak, heyecan arayan kimselerin davranıșa yönelik risklerini düșük olarak değerlendirmektedirler (Hoyle ve diğerleri, 2002). Wong ve Carducci (1991) de finansal risk alma ile 
heyecan aramanın ilișkisine kanıt sunmaktadır. Buradan hareketle, heyecan aramanın finansal risk toleransı üzerinde etkisi olacağı öngörülmektedir.

\subsection{Finansal Risk Toleransı}

Grable (2000: s. 625), finansal risk toleransını, bir kimsenin finansal bir karar verirken kabul edebileceği maksimum belirsizlik miktarı olarak tanımlamaktadır. Bu kavram, finansal bir dizi riskli duruma yönelik kișinin risk alma tavrını ölçmektedir. Araștırmacılar, finansal risk toleransını demografik ve sosyoekonomik faktörlerle ilișkilendirmiștir. Özellikle, finansal hizmet uzmanlarının yatırımcıların finansal risk toleransını tahmin etmek için yaygın biçimde kestirme yargılara bașvurdukları görülmektedir (Roskowski ve diğerleri, 1993). Buna göre, örneğin, nispeten yașlı kimselerin daha az finansal risk toleransına sahip olduğu kabul edilir (Grable ve Lytton, 1998). Bireylerin risk profillerinin değerlendirmede genel olarak dört faktörün kullanıldığı görülmektedir (Garman ve Forgue (1997)'den aktaran Larkin ve diğerleri, 2013). Bunlar, amaçlar, zaman ufku, finansal istikrar ve risk toleransıdır. Diğer faktörlere kıyasla, risk toleransının görece sübjektif niteliği bulunmakta ve bu özelliği ölçümünü zorlaștırmaktadır.

Cinsiyet, yaș, eğitim, gelir ve medeni hal gibi demografik faktörlerin finansal karar verme ya da davranıș üzerindeki etkileri üzerine literatürde fazlasıyla bir odaklanma bulunmaktadır (örn., Adhikari \& O'leary, 2011; Ansong ve Gyensare, 2012; Bajtelsmit ve Bernasek, 1996; Barber \& Odean, 2001; Charness ve Gneezy, 2012; Dwyer ve diğerleri, 2002; Duasa ve Yusof, 2013; Grable ve Lytton, 1998; Grable ve Joo, 1999; Hallahan ve diğerleri, 2004; Grable ve Joo, 2004; Jianakoplos ve Bernasek, 2006; Lutfi, 2010; Halko ve diğerleri, 2012; Gong ve Yang, 2012; Lai ve Tam, 2012; Kamas ve Preston, 2012; Larkin ve diğerleri, 2013; Powel ve Ansic, 1997; Roszkowski ve Grable, 2005; Selcuk ve diğerleri, 2010; Sung ve Hanna, 1996; Yao ve Hanna, 2005). Hatta davranışsal finansın aksiyomlarıyla birlikte, davranısssal ve tutumsal faktörler mercek altına alınana değin finans literatüründe çoğunlukla odaklanmanın 
demografik faktörler üzerinde olduğu söylenebilir. Bütün bu faktörlerden üzerinde görüș birliği olanın cinsiyet olduğu söylenebilir.

Demografik ve sosyoekonomik faktörlerden farklı olarak finansal bilgi, kontrol odağı gibi bireysel faktörler de finansal risk toleransının belirleyicileri olarak çok sınırlı sayıda karșımıza çıkmaktadır. Örneğin, Grable ve Joo (2000) kontrol odağının, finansal bilginin finansal risk toleransının belirleyicileri olduğuna kanıt sunmaktadır. Benzer șekilde, Selçuk ve diğerleri (2000) belirsizlikten kaçınmanın finansal risk toleransı ile negatif ilișkili olduğunu göstermekte aynı zamanda çalıșılan sektörün de etkili olduğunu söylemektedir. Özel sektör çalıșanları kendi kendine seçme etkisiyle kamu sektörü çalışanlarına göre daha fazla finansal risk toleransına sahiptir.

Çeșitli kișilik ve davranıș faktörlerinin de finansal risk toleransı üzerinde etkili olabileceği düșünülmektedir. Örneğin, Wong ve Carducci (1991) heyecan arayanların daha fazla finansal risk toleransına sahip olduğunu ortaya koymaktadır. Dolayısıyla bu çalıșmada, bir kișilik faktörü olarak Tip A davranıș kalıbının ve heyecan arama özelliğinin finansal risk toleransı ile bağlantısı kurulmaktadır. Daha açık bir ifadeyle, Tip A davranıșına sahip kimselerin ve heyecan arayan bireylerin finansal risk toleransının yüksek olması beklenmektedir.

\section{Araștırma Metodolojisi}

\subsection{Araștırma Modeli ve Değișkenlerin Ölçümü}

Önceki araștırmalara dayanarak, öne sürülen araștırma modeli șekil 2.1'de görülmektedir.

\section{Șekil 3.1. Araștırma Modeli}

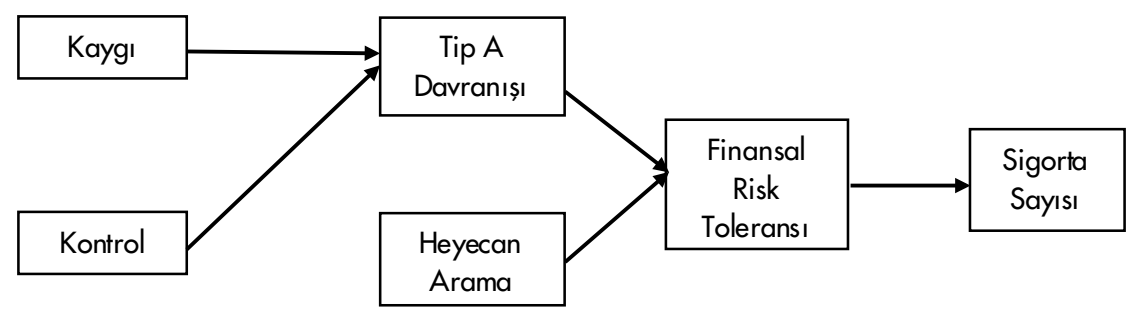


Araștırma modelinden çıkan hipotezler ise așağıdaki gibi sıralanabilir:

H1: Kaygı, Tip A davranıș kalıbı ile pozitif ilișkilidir.

H2: Kontrol odağı, Tip A davranıș kalıbı ile pozitif ilișkilidir.

H3: Tip A davranıșı finansal risk toleransı ile pozitif ilișkilidir. dir.

H4: Heyecan arama finansal risk toleransı ile pozitif ilișkili-

H5: Finansal risk toleransı sigorta sayısı ile pozitif ilișkilidir.

Araștırmanın Tip A kișiliği, kontrol odağı, kaygı değișkenlerini ölçümlemede $5^{\prime}$ li likert tipi ölçek kullanılmıștır. Buna göre 1; "kesinlikle katılmıyorum", 5; "kesinlikle katılıyorum" seçeneklerini temsil etmektedir. Finansal risk toleransı ve heyecan arama ölçekleri seçeneklere atfedilen puanlar aracılığıyla hesaplanmıștır.

Tip A Davranıșı: Tip A davranıș kalıbını ölçümlemek üzere on maddelik tek boyutlu bir ölçek (Mudrack, 1999) kullanılmıștır. Tek boyutlu olmasına karșın, ölçek söz konusu davranış kalıbının üç cephesini içermektedir. Bunlar, zaman baskısı, rekabetçi güdü ve iș baskısı algısıdır. Yüksek skorlar, bu davranıșın varlığına yüksek ölçüde ișaret etmektedir.

Heyecan Arama: Heyecan aramayı ölçebilmek üzere Zuckerman (1996) tarafından ortaya atılan 40 maddelik ölçeğin 13 maddeye kısaltılmıs versiyonundan faydalanılmıștır. Tercih edilen seçeneklere atanan puanların toplanması ile her bir bireyin heyecan arama skoru hesaplanır. Yüksek skorlar, yüksek heyecan aramaya ișaret etmektedir.

Kontrol Odağı: Kontrol odağı değișkenini ölçmede Perry ve Morris (2005)'ten faydalanılmıștır. Söz konusu ölçek 7 maddeden olușmakta ve yüksek skorlar dıșsal kontrol odaklı kimseleri temsil etmektedir.

Kaygı: Bireyin son günlerde ne kadar kaygı altında olduğunu ölçümlemek amacıyla Lee ve diğerleri (1996)'dan istifade edilmiștir. Buna göre yüksek skorlar, bireyin son günlerde kaygı alında olduğuna ișaret etmektedir. 
Finansal Risk Toleransı: Finansal risk toleransını ölçümlemek üzere Gilliam ve diğerleri (2010)'dan faydalanılmıștır. Ölçek çoktan seçmeli olup, on üç farklı risk senaryosuna verilecek cevapların puanlanması ile hesaplanmaktadır. Buna göre, puanlar belirlenmiș bir derecelendirmeye göre bireyleri düșük, orta alt, orta, orta üst ve yüksek olmak üzere kategorilere ayırmaktadır.

Sigorta Sayısı: Türkiye'de yapılan bir çalıșmada (Ozdemir \& Yilmaz, 2011) Zorunlu Deprem Sigortasının risk azaltma davranıșının varlığına bir gösterge olarak kullanıldığı görülmektedir. Bu bakımdan, risk azaltma stratejisini ölçümlendirmek üzere, bunun bir göstergesi olan sigorta tedbiri sayısı kullanılmıștır. Bireylerin kendi iradeleri ile tercih ettiği ve primlerini ödediği (çalıștıkları șirket tarafından yapılan ve primleri ödenenler hariç) sigorta adedini göstermektedir. Bu çerçevede bireylere on bir farklı sigorta çeșidi sunulmuș ve hangilerine sahip oldukları ve primlerini ödedikleri sorulmuștur.

\subsection{Araștırma Örneklemi}

Araștırma veri seti, internet ortamında sunulan anketin, gönüllülük esası ve kolayda örnekleme ile seçilen bireyler tarafından doldurulması ile elde edilmiștir. Buna göre, ankete cevap veren toplam 71 bireyin 35'i erkek, 36'sı kadındır. 36 kiși 20-30 ve 24 kiși de 31-40 yaș aralığındadır. Dolayısı ile deneklerin yaklașık \% 85'i 40 yaș alıı genç kesimdir. Deneklerin yaklașı \%95'i üniversite ve yüksek lisans/dokłora mezunudur. 37 birey evli ve 34 birey bekârdır. Genel olarak bakıldığında, cinsiyet ve medeni durum olarak dengeli, genç ve iyi eğitimli bir denek grubu araștırma verisini olușturmaktadır.

\section{3. Ölçek Geçerliliği ve Güvenilirliği}

Tip A davranıșı, kaygılı olma, kontrol odağı ve heyecan arama ölçeklerine ilișkin maddeler bir bütün olarak açıklayıcı faktör analizine tabi tutulmuștur. Açıklayıcı faktör analizinin tercih edilme sebebi, ilgili değișkenlerin, özüne sadık kalınmakla birlikte, ilk defa bizim tarafımızdan Türkçe'ye tercüme edilmesi ile yeni ölçeklerin olușmuș olmasıdır. Illgili faktör analizinin nihai sonuçları Tablo 3.1'de sunulmuștur. 


\section{Tablo 3.1: Fakłör ve Güvenirlik Analizleri}

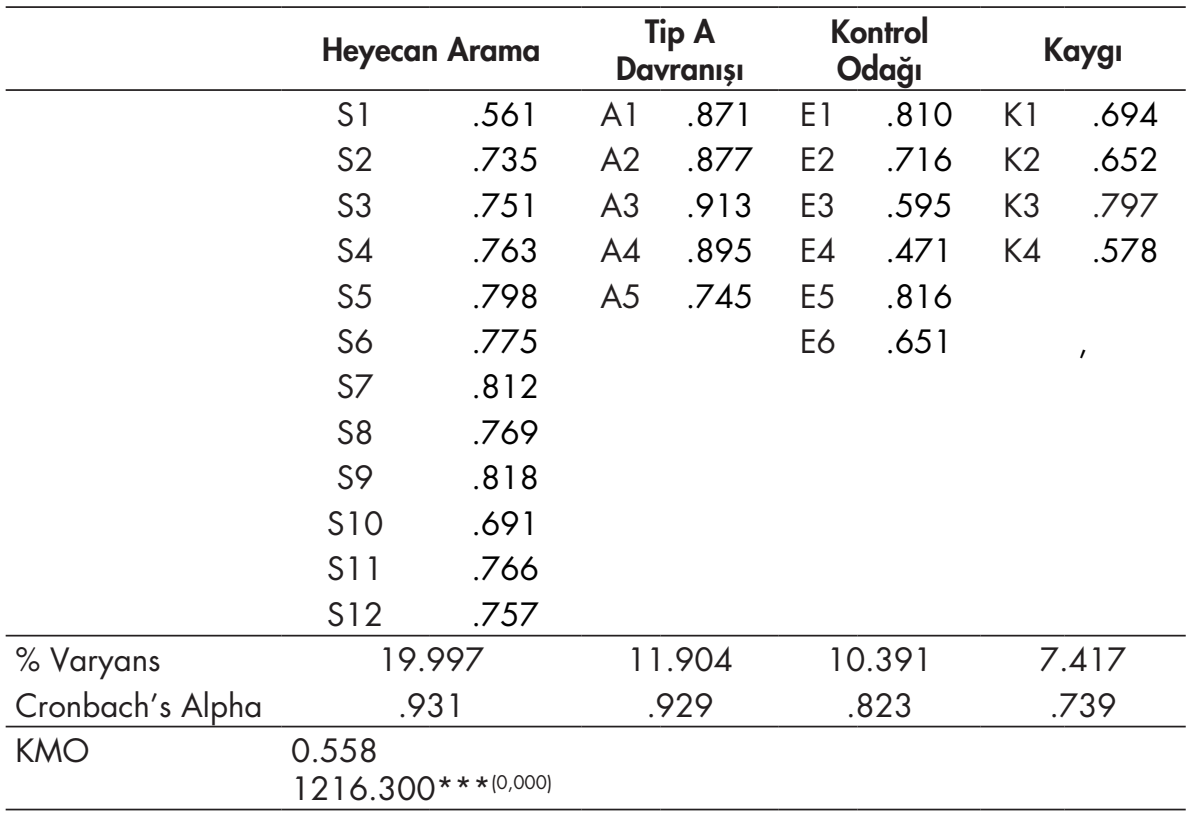

Verilerin faktör analizine uygunluğunun göstergesi olarak hesaplanan Bartlett's test değeri 1216,300 olarak hesaplanmıș ve 0,000 hata seviyesinde anlamlı bulunmuștur. Veri değerlerinin tutarlılığını gösteren KMO değeri için, Field (2000) alt sınırın 0,50 olması gerektiğini ve daha küçük KMO değerleri için faktör analizinin yapılamayacağını belirtmiștir. Veri setimiz için hesaplanan değer 0,558 olup, alt sınırın üstündedir. Bu temel test değerleri neticesinde veri setinin faktör analizine uygun olduğu söylenebilir.

Faktör analizi sonucunda, teorinin öngördüğü șekilde dört faktör olușmuștur. Buna göre, ölçek geçerliliğinin olduğu söylenebilir. Hair, Black, Babin, \& Anderson (2010, s.96) faktör analizi sonuçlarının diğer çok değișkenli data tekniklerine esas olușturduğunu söylemekte ve hatta aynı çalıșmada (s.708) faktör analizinin yapı geçerliliğini değerlendirmede kullanıldığını belirtmektedir. Faktör analizinde kavramsal anlamlılığı olmayan faktörlere yüklenen ölçek maddeleri elenmiștir. Bunun neticesinde heyecan arama faktörü 12 (bir madde elenmiștir), Tip A davranıșı faktörü 5 (beș madde elen- 
miștir), kontrol odağı faktörü 4 (üç soru elenmiștir) ve kaygı faktörü de 4 (bir madde elenmiștir) maddeden olușmuștur.

Her faktöre ilișkin ayrı ayrı güvenirlik analizleri yapılmıș ve her faktörün içsel tutarlılığını gösteren Cronbach's Alpha değerleri Tablo 3.1'de gösterilmiștir. Tüm faktörlere ait güvenirlik değerleri, 0.70 kabul edilebilir seviyenin (Nunnally \& Bernstein, 1994) üzerinde çımıștır. Faktör ve güvenirlik analizleri sonucunda araștırma modelinde kullanılan dört faktöre ulașılmıștır.

\subsection{Analiz ve Bulgular}

Șekil 1'den de görüleceği gibi kaygılı olma ve kontrol odağı değișkenlerinin Tip A davranıșını etkilediği ve Tip A davranıșı ile heyecan aramanın bireylerin finansal risk tolerans düzeylerini belirlediği ve onun da yaptırılan sigorta sayısını etkilediği öngörülmüștür. Bu çerçevede modelin regresyon analizi ile testi gerçekleștirilmiștir. Buna göre ilk olarak ilgili değișkenlerin korelasyon analizi yapılmıștir (Tablo 3.2).

\section{Tablo 3.2: Korelasyon Analizi Sonuçları}

\begin{tabular}{lcccccc}
\hline & Tip A & Kaygı & $\begin{array}{c}\text { Kontrol } \\
\text { Odağı }\end{array}$ & Risk Toleransı & $\begin{array}{c}\text { Heyecan } \\
\text { Arama }\end{array}$ & $\begin{array}{c}\text { Sigorta } \\
\text { Sayısı }\end{array}$ \\
\hline Tip A & 1 & $\mathbf{4 0 2 *}^{*}$ & $\mathbf{, 3 5 6 *}^{* *}$ & $\mathbf{2 6 4}^{*}$ &, 030 &,- 008 \\
Kaygı & & 1 & $\mathbf{4 0 3 *}^{* *}$ &, 001 &,- 012 &,- 087 \\
Kontrol Odağı & & & 1 &,- 029 &,- 077 &, 075 \\
$\begin{array}{l}\text { Finansal Risk } \\
\text { Toleransı }\end{array}$ & & & 1 &, $\mathbf{3 4 9}^{* *}$ & $\mathbf{, 2 4 3}^{*}$ \\
Heyecan Arama & & & & & 1 &,- 025 \\
\hline
\end{tabular}

**: \% 1 hata düzeyinde anlamlı; *: \% 5 hata düzeyinde anlamlı.

Korelasyon analizi modelde öngörülen ilișkilerin ikili boyutta ve anlamlı olduğunu göstermektedir. A tipi kișiliğin kaygılı olma ve kontrol odağı ile tahmin edildiği regresyon eșitliği sonucuna göre, araștırmanın ilgili hipotezleri desteklenmektedir. Bir bașka ifadeyle, kaygılı olma ve kontrol odağı Tip A kișiliği üzerinde istatistiksel olarak anlamlı etkiye sahiptir. Tablo 3.3 ilgili regresyon eșitliği sonuçlarını göstermektedir. 
Tablo 3.3: Tip A Davranıșı $=a_{0}+a_{1}($ Kaygı $)+a_{2}$ (Kontrol odağı $)+$ u Regresyon Modeli Sonuçları

\begin{tabular}{lcc}
\hline & Standartlaștırılmıș Katsayılar & Anlamlılık \\
\hline Kaygı & 0,308 & 0,011 \\
Kontrol Odağı & 0,231 & 0,054 \\
\hline Düzeltilmiș R $\mathbf{R}^{2}$ & $0,183^{* *}(0,000)$ \\
\hline
\end{tabular}

Tablo 3. 3'de görüleceği gibi kaygılı olma ve kontrol odağı ile A tipi davranıș kalıbındaki değișimin \%18,3'ü açıklanmaktadır ve model 0,000 hata seviyesinde anlamlı bulunmaktadır. Modelde yer alan iki değișkenden kaygılı olma 0,05 hata seviyesinde ve kontrol odağı 0,10 hata seviyesinde anlamlıdır ve her ikisi de A tipi davranıșı ile pozitif ilișkilidir.

Bunu takiben, A tipi kișiliği ve heyecan aramanın bireylerin finansal risk tolerans düzeylerine etkisi araștııılmıștır. Regresyon analizi sonuçları Tablo $3.4^{\prime}$ de gösterilmiștir.

\section{Tablo 3.4: Finansal Risk Toleransı $=a_{0}+a_{1}$ (Tip A Davranıșı) $+a_{2}$ (Heyecan Arama)+ u Regresyon Modeli Sonuçları}

\begin{tabular}{lcl}
\hline & Standartlaștırılmıș Katsayılar & Anlamllık \\
\hline Tip A Davranıșı & 0,255 & 0,025 \\
\hline Heyecan Arama & 0,296 & 0,010 \\
\hline Düzeltilmiș $\mathbf{R}^{2}$ & \multicolumn{2}{c}{$0,132^{* * 0,003)}$} \\
\hline
\end{tabular}

Bu model de 0,01 hata seviyesinde anlamlıdır ve bağımsız değișkenler bireylerin finansal risk toleransındaki değișimin \%13,2'sini açıklamaktadır. Her iki değișken de 0,05 hata seviyesinde anlamlıdır ve bağımlı değișkenle pozitif yönde ilișkilidir.

\section{Tablo 3.5: Sahip Olunan Sigorta Sayısı $=a_{0}+a_{1}$ (Finansal Risk Toleransı) + u Regresyon Modeli Sonuçları}

\begin{tabular}{lcc}
\hline & Standartlaștırılmıș Katsayılar & Anlamlılık \\
\hline Finansal Risk Toleransı & 0,243 & 0,041 \\
\hline Düzeltilmiș $\mathbf{R}^{2}$ & \multicolumn{2}{c}{$0,045^{*}(0,041)$} \\
\hline
\end{tabular}


Son olarak finansal risk toleransının sahip olunan sigorta sayısına etkisi araștırılmıștır. Tablo 3.5'de görüldüğü üzere, etki mevcuttur ve 0,05 hata seviyesinde anlamlidır.

Yapılan analizler çerçevesinde son günlerde kaygılı olmanın ve kontrol odağının Tip A kișiliğine etkide bulunduğu ve Tip A kișiliğinin ve heyecan aramanın bireylerin finansal risk toleransı üzerinde anlamlı faktörler olduğu istatistiksel olarak ortaya çıkmıștır. Son olarak, finansal risk toleransı da bireylerin yaptırdığı sigorta sayısı ile pozitif ilișki içindedir.

\section{Tartıșma ve Sonuç}

\subsection{Teorik ve Pratik Çıkarsamalar}

Bu araștırmada bireylerin sigorta tercihleri ve sayısı üzerinde etkide bulunması muhtemel davranıșsal ve tutumsal öğeler araștııımıștır. Literatürde risk alma ile ilișkisi ortaya konan Tip A davranıșı ve heyecan aramanın finansal risk toleransı üzerinde, bunun da sahip olunan sigorta sayısı üzerindeki olası etkileri gözlemlenmiștir. Ayrıca, Tip A davranıș kalıbını bireylerin son günlerde kaygılı hissetmelerinin ve eylemlerinin sonuçlarını kendilerinden ziyade dışsal șans, talih, kader gibi dıșsal faktörlere bağlamalarının etkileyebileceği öngörülmüștür.

Analiz sonuçları, gerçekten de, son günlerde kendilerini görece kaygılı hisseden bireylerin ve kaderci diyebileceğimiz kișisel kontrolü görece düșük kimselerin Tip A davranıșını göstermeye meyilli olduklarını göstermektedir. Ayrıca Tip A davranıșının ve heyecan aramanın birlikte finansal risk toleransını etkilediği ortaya çıkmıștır. Bunlar, var olan literatüre katkı yapması beklenen bulgulardır. Cünkü finansal risk toleransının belirleyicileri üzerine yapılan araștırmalar çoğunlukla demografik ve sosyoekonomik faktörlere odaklanmıșlardır (örn., Roskowski ve diğerleri, 1993). Dolayısıyla bu faktörlerden bașka finansal ve riskli karar vermeleri etkilemek noktasında davranıșsal ve tutumsal öğelerin ve kișilik faktörlerinin de önemli olduğu bulgusunun davranıșsal finans literatürüne değerli katkılar yapması beklenmektedir. Daha da önemlisi, finansal risk toleransının sahip olunan ve bireylerin tamamen kișisel talep 
ve tasarrufları doğrultusunda sahip oldukları sigorta sayısını etkilemesi ilk bakıșta așikâr bir sonuç gibi görülebilir. Ama kaygılı olma, dıșsal kontrol odağına sahip bulunma, Tip A davranıșı gösterme ve heyecan arama eğiliminde olmanın finansal risk toleransı üzerinden sahip olunan risk sayısını etkiliyor olması değerli bir bulgu olabilir. Çünkü bu bulgu, aynı zamanda, bireylerin risk azaltma stratejilerinde, riski yönetme biçimlerinde davranışsal ve tutumsal öğelerin devrede olduğu anlamına gelmektedir. Geleceğin belirsizliği ve bununla baș etme yöntemlerinde, literatürde çokça odaklanılan ve doğrudan gözlemlenebilir olan öğelerden bașka, psikolojik öğelerin anlamlı olması davranışsal finansa hizmet eden, olan davranıșı açıklayıcı bir bulgudur.

Bu bulguların, pratik anlamda değerli çıkarımları da olabilir. Bu bulguya göre, sigorta șirketlerinde hizmet veren profesyonellerin kestirme yargılamalarda bulunurken sadece demografik ve sosyoekonomik göstergeleri kullanması yetersiz kalabilir. Bunların yanı sıra, bireylerin kișilikleri ve tutumları gereği finansal riske tahammül edebilir ya da edemeyebilir olmaları da mümkün gözükmektedir. Dolayısıyla, sigorta hizmeti verenlerin bu faktörleri de göz ardı etmemeleri yerinde olabilir.

\subsection{Kısıtlar ve Öneriler}

Her araștırmada olduğu gibi, bu araștırmada da bazı kısıtlamalar bulunmaktadır. Öncelikle, daha geniș bir örneklem ile daha genelleștirilebilir sonuçlar elde edileceği açıktır. Dolayısıyla, bu araștırma sonuçlarını değerlendirirken örneklem hacmi göz önünde bulundurulmalıdır. İkincisi, yatay kesit verileri yerine zamana ve bireylere bağlı değișmeyi göz önünde bulunduran boylamsal verilerle önerilen nedensel ilișkileri sorgulamak daha uygun olabilir. Üçüncüsü, araștırma modelinde bazı değișkenlerin (örneğin finansal risk toleransı) hem bağımsız hem bağımlı değișken rolünü tașıdığı yani ara değișken etkisine sahip olduğu görülmektedir. Bu çalıșmada, araștırma modeli regresyon modeli ile parçalı olarak test edilmiștir. Daha geniș bir örneklem ile modelin tamamını eșanlı tahmin edebilen yapısal eșitlik modellemesini kullanmak ve ölçüm hatalarını da hesaba katan daha doğru ve güçiü tahmin katsayılarına ulașmak 
mümkün olabilir. Bu bakımdan, ileriki araștırmaların yapısal eșitlik modellemesinden faydalanması önerilmektedir.

Dördüncüsü, örneklem karakteristiğini ortaya koymak üzere katılımcılara, yas, cinsiyet, medeni hal, gelir ve eğitim düzeyleri sorulmuștur. Modelin içine bu faktörler finansal risk toleransının açıklayıcı değișkenleri olarak dâhil edilip, tutumsal ve davranıșsal öğelerle birlikte etki büyüklükleri karșılaștırılabilir. Böylelikle demografik öğelerin ötesinde psikolojik öğelerin artımsal geçerliliği de sorgulanmıș olabilir.

\section{KAYNAKLAR}

Adhikari, B.K., V. O'leary. 2011 . Gender Differences in Risk Aversion: A Developing Nation's Case. Journal of Personal Finance, 10 (2): 122-147.

Anbar, A., M. Eker. 2009. Bireysel Yatırımcıların Finansal Risk Algılamalarını Ełkileyen Demografik ve Sosyoekonomik Faktörler. ZKÜ Sosyal Bilimler Dergisi, 5 (9): 129-150.

Ansong, A. and M.A. Gyensare. 2012. Determinants of University WorkingStudents' Financial Literacy at The University of Cape Coast, Ghana. International Journal of Business and Management, 7 (9): 126-133.

Bajtelsmit, V.L., A. Bernasek. 1996. Why Do Women Invest Differently Than Men? Financial Counseling and Planning, 7:1-10.

Barber, B.M., T. Odean. 2001. Boys will be boys: Gender, Overconfidence and Common Stock Investment. Quarterly Journal of Economics, 1 16: 261292.

Bond, M.J., N.T. Feather. 1988. Some Correlates of Structure and Purpose in The Use Of Time. Journal of Personality and Social Psychology, 55: 321 329.

Botzen, W.J.W., Aerts, J.C.J.H., \& Van Den Bergh, J.C.J.M. 2009. Willingness of Homeowners to Mitigate Climate Risk Through Insurance. Ecological Economics, 68: 2265-2277.

Carducci, B.J., A.S. Wong. 1998. Type A and Risk Taking in Everyday Money Matters. Journal of Business and Social Psychology, Vol. 12 (3): 355-359.

Charness, G., U. Gneezy. 2012. Strong Evidence for Gender Differences in Risk Taking. Journal of Economic Behavior \& Organization, 83: 50-58.

Duasa, J., S.A. Yusof. 2013. Determinants of Risk Tolerance on Financial Asset Ownership: A Case of Malaysia. International Journal of Business and Society, 14 (1): 1-16. 
Dwyer, P.D., J.H. Gilkeson, J.A. List. 2002. Gender Differences in Revealed Risk Taking: Evidence From Mutual Fund Investors. Economics Letters, 76:151-158.

Field, A. P., ed. 2000. Discovering Statistics Using SPSS for Windows: Advanced Techniques for Beginners, 1 st, Sage Publications, Inc. Thousand Oaks, CA, USA.

Gong, B., C. Yang. 2012. Gender Differences in Risk Attitude: Field Experiments on The Matrilineal Mosuo and The Patriarchal Yi. Journal of Economic Behavior \& Organization, 83: 59-65.

Grable, J. E. 2000. Financial Risk Tolerance and Additional Factors that Affect Risk Taking in Everyday Money Matters. Journal of Business and Psychology, $14(4): 625-630$.

Grable, J. E. 2000. Financial Risk Tolerance and Additional Factors that Affect Risk Taking in Everyday Money Matters. Journal of Business and Psychology, 14 (4): 625-630.

Grable, J., R.H. Lytton. 1999. Financial Risk Tolerance Revisited: The Development of A Risk Assessment Instrument. Financial Services Review, 8: 163181.

Grable, J.E. \& R.H. Lytton. 1998. Investor Risk Tolerance: Testing The Efficacy of Demographics As Differentiating and Classifying Factors. Financial Counseling and Planning, Vol. 9: 61-74.

Grable, J.E. \& S. Joo. 2000. A Cross-Disciplinary Examination of Financial Risk Tolerance. Consumer Interests Annual, 46: 151-157.

Grable, J.E., R.H. Lytton. 1998. Investor Risk Tolerance: Testing The Efficacy of Demographics As Differentiating and Classifying Factors. Financial Counseling and Planning, 9 (1): 61-74.,

Grable, J.E., S. Joo. 1999. Factors Related To Risk Tolerance: A Further Examination. Consumer Interests Annual, 45: 53-58.

Grable, J.E., S., Joo. 2004. Environmental and Biopsychosocial Factors Associated With Financial Risk Tolerance. Financial Counseling and Planning, 15 (1): 73-82.

Hair, J. F., Black, W.C., Babin, B.J., \& Anderson, R.E. (2010). Multivariate data analysis: A global perspective, 7th Edition, New Jersey, USA: Pearson Prentice Hall.

Halko, M.L., M. Kaustia, E. Alanko. 2012. The Gender Effect in Risky Asset Holdings. Journal of Economic Behavior \& Organization, 83: 66-81.

Hallahan, T.A., R.W. Faff, M.D. McKenzie. 2004. An Empirical Investigation of Personal Financial Risk Tolerance. Financial Services Review, 13: 57-78. 
Heino, A., H.H. Van Der Molen, G.J.S. Wilde. 1996. Differences in Risk Experience Between Sensation Avoiders and Sensation Seekers. Personality and Individual Differences, Vol. 20: 21-79.

Horvath, P., M. Zuckerman. 1993. Sensation Seeking, Risk Appraisal and Risky Behavior. Personality and Individual Differences, 14: 41-52.

Hoyle, R.H., M.C. Fejfar, J.D. Miller. 2000. Personality and Sexual Risk Taking: A Quantitative Review. Journal of Personality, 68, 1203-1231.

Jianakoplos, N.A., A. Bernasek. 2006. Financial Risk Taking by Age, and Birth Cohort. Southern Economic Journal, 72 (4): 981-1001.

Kamas, L., A. Preston. 2012. The Importance of Being Confident; Gender, Career Choice, and Willingness to Compete. Journal Of Economic Behavior \& Organization, 83: 82-97.

Koonce, L., McAnally, M.L., \& Mercer, M. (2005). How Do Investors Judge The Risk of Financial Items? The Accounting Review, 80: 221-241.

Lai, P, K. Tam. 2012. Gender Discrepancy's Impact on Perceived Risk and Investment Decision: A Review of Financial Practitioners Behavior in Hong Kong, China. Journal of Advances Research in Management, 3, Iss. 1 (5): 27-37.

Larkin, C., B.M. Lucey, M. Mulholland. 2013. Risk Tolerance and Demographic Characteristics: Preliminary Irish Evidence. Financial Services Review, 22: 77-91.

Lutfi. 2010. The Relationship Between Demographic Factors and Investment Decision in Surabaya. Journal of Economics, Business and Accountancy Ventura, 13 (3): 213-224.

MacGregor, D., Slovic, P., Berry, M., \& Evensky, H.R. 1999. Perception of Financial Risk: A Survey of Advisors and Planners. Journal of Financial Planning, 12:68-86.

Mudrack, P. 1999. Time Structure and Purpose, Type A Behavior, and The Protestant Work Ethic. Journal of Organizational Behavior, 20: 145-158.

Nunnally, J.C., \& Bernstein, I.H., (1994), "Psychometric Theory", NY: McGrawHill Inc.

Ozdemir, O. \& Yilmaz, C. 2011 . Factors Affecting Risk Mitigation Revisited: The Case of Earthquake in Turkey, Journal of Risk Research, 14 (1): 17-46.

Powell, M., D. Ansic. 1997. Gender Differences in Risk Behaviour in Financial Decision-Making: An Experimental Analysis. Journal of Economic Psychology, 18: 605-628.

Price, V.A., ed. 1982. Type A Behavior Pattern: A Model for Research and Practice, Academic Press, New York. 
Roszkowski, M.J., G. Davey, J.E. Grable. 2005. Insights From Psychology and Psychometrics on Measuring Risk Tolerance. Journal of Financial Planning, April 2005: 66-77.

Roszkowski, M.J., G.E. Snelbecker, \& S.R. Leimberg. 1993. Risk Tolerance and Risk Aversion, içinde Leimberg, S.R., Satinsky, M.J., LeClair, R.T. \& Doyle, R.J. Jr. (Editörler). The Tools and Techniques of Financial Planning (4. Baskı: 213-226). Cincinnati, OH: National Underwriter.

Roszkowski, M.J., J.E. Grable. 2005. Estimating Risk Tolerance: The Degree of Accuracy and The Paramorphic Representations of the Estimate. Financial Counseling and Planning, 16 (2): 29-47.

Sachse, K., H. Jungermann, J.M. Belting. 2012. Investment Risk- The Perspective of Individual Investors. Journal of Economic Psychology, 33: 437-447.

Selcuk, E., A. Altinoklar, G. Aydin. 2010. Financial Risk Tolerance: Scale Development and Analysis of Determinants. Journal of American Academy of Business, 15 (2): 89-97.

Siebenmorgen, N., Weber, M. (1999). Risikowahrnehmung. Wie Anleger Unsichere Renditen Einschatzen (Forshchung für die Praxis, Band 4). Mannheim: Universtat, Lehrstuhl für ABWL, Finanzwirtschaft Insbesondere Bankbetriebslehre.

Sitkin, S.B., A.L. Pablo. 1992. Reconceptualizing the determinants of risk behaviour. Academy of Management Review, 17: 9-38.

Sung, J., S. Hanna. 1996. Factors Related to Risk Tolerance. Financial Counseling and Planning, 7: 11-19.

Weber, E.U., A. Blais, E.N. Betz. 2002. A Domain-Specific Risk- Attitude Scale: Measuring Risk Perceptions and Risk Behaviors. Journal of Behavioral Decision Making, 15 (4): 263-290.

Wong, A., B.J. Carducci. 1991. Sensation Seeking and Financial Risk Taking in Everyday Money Matters. Journal of Business and Psychology, 5: 525. 530.

Yao, R., S.D. Hanna. 2005. The Effect of Gender and Marital Status on Financial Risk Tolerance. Journal of Personal Finance, 4 (1): 66-85.

Zuckerman, M. 1996. Item Revisions in The Sensation Seeking Scale Form V (SSS-V). Personality and Individual Differences, 20: 515. 